\title{
FIND OF GALLIENUS ANTONINIANUS CONTEMPORARY FORGERY FROM THE PUSTÝ HRAD CASTLE IN ZVOLEN, SLOVAKIA ${ }^{1}$
}

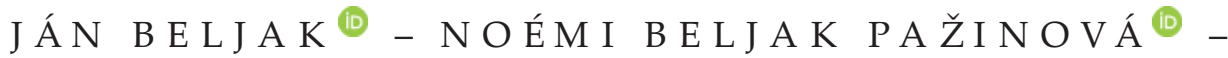 \\ B ORIS STOKLAS
}

\begin{abstract}
The paper discusses a single find of a Roman coin - a subaerat Gallienus antoninianus - a random find from the Pustý hrad (Deserted) Castle in Zvolen. The find corroborates the view that the site was settled in the Early or Late Roman Period. The coin is a Roman currency commonly used in trade with the Quadi. A thorough analysis of the coin allowed us to determine its age, method of production and interpret its historical context. So far, no similar contemporary finds of young subaerat antoninianus coins are known from the Danubian Barbaricum.
\end{abstract}

Keywords: Central Slovakia, castle, antoninianus forgery, Late Roman Period.

We have known imitations or counterfeit coins since the times of antiquity (Kolníková 1978). The introduction of coins as a currency and a generic equivalent of a value was extremely important for the development of the economy and mainly trade - local as well as long-distance. Coins were considerable concentrations of precious metals and their values. Thus, they allowed faster cumulation of property and fortune. Counterfeiters of coins or coiners were primarily greedy and although their activity was illegal, the attractivity of economic prosperity was stronger than their fear of punishment. In the Late Roman Period, a large number of coins of various quality, including counterfeit exemplars, was in circulation. Money in general was losing its value in the $3^{\text {rd }}-4^{\text {th }} \mathrm{c}$. AD. The proportion of precious metal was reduced on purpose, which led to the devaluation of coins and a disproportionate increase in their number. Circulating counterfeit money or fake coins were successful mainly in politically or socially unstable times. For counterfeiters, imitation of coins' value by imitating the design but using a lower proportion of precious metal was important (Hunka 2013, 131). Expansion of imitating was thus an inseparable part of the use of coins.

The presented article aims to present the unique find of a contemporary imitation of a subaerat antoninianus of the emperor Gallienus (Fig. 1: 1). The coin was accidentally discovered in the mixed cultural layer of trench 1A studied in the summer season of 2018 at the courtyard near the entrance gate of the National Cultural Monument of Pustý hrad (Deserted) Castle in Zvolen (Fig. 2; 3). Excavations at this site have been carried out systematically since 1992 every summer, until now. It was started by archaeologist V. Hanuliak, with whom the monument's renovation is associated. Since 2009, the research and renovation have been coordinated by the Institute of Archaeology of SAS in Nitra and led by J. Beljak. The long-term goal is not only the renovation of the castle as a monument but also protecting the monument and its presentation for the generations now and in the future (Beljak Pažinová/Beljak 2020).

The perennial modern systematic research of the Pustý hrad Castle in Zvolen has brought numerous movable as well as immovable finds which elucidate the extent and the character of the settlement from prehistory to the High Middle Ages and gradually explain the construction in the area and its catchment area (Beljak/Beljak Pažinová/Šimkovic 2018, 3-63; Beljak et al. 2014; Pažinová et al. 2013). As late as season 2018, no finds from the Roman Period were known from the site of Pustý hrad Castle in Zvolen, which the discovery of the counterfeit antoninianus of emperor Gallienus definitely changed. We aim to present the find context, analyse the coin itself and its possible role in the historical context of Germanic settlement in the territory of the central Pohronie region in the Late to Final Roman Period.

\footnotetext{
1 The contribution was created in the frame of VEGA project No. 1/0240/21 The landscape and settlements of the Celts and Germani Mutual relations, relations in and with the landscape and VEGA project No. 2/0018/19 Ecological Analyses of Landscape Acculturation in Slovakia since Early Prehistory until Today.
} 


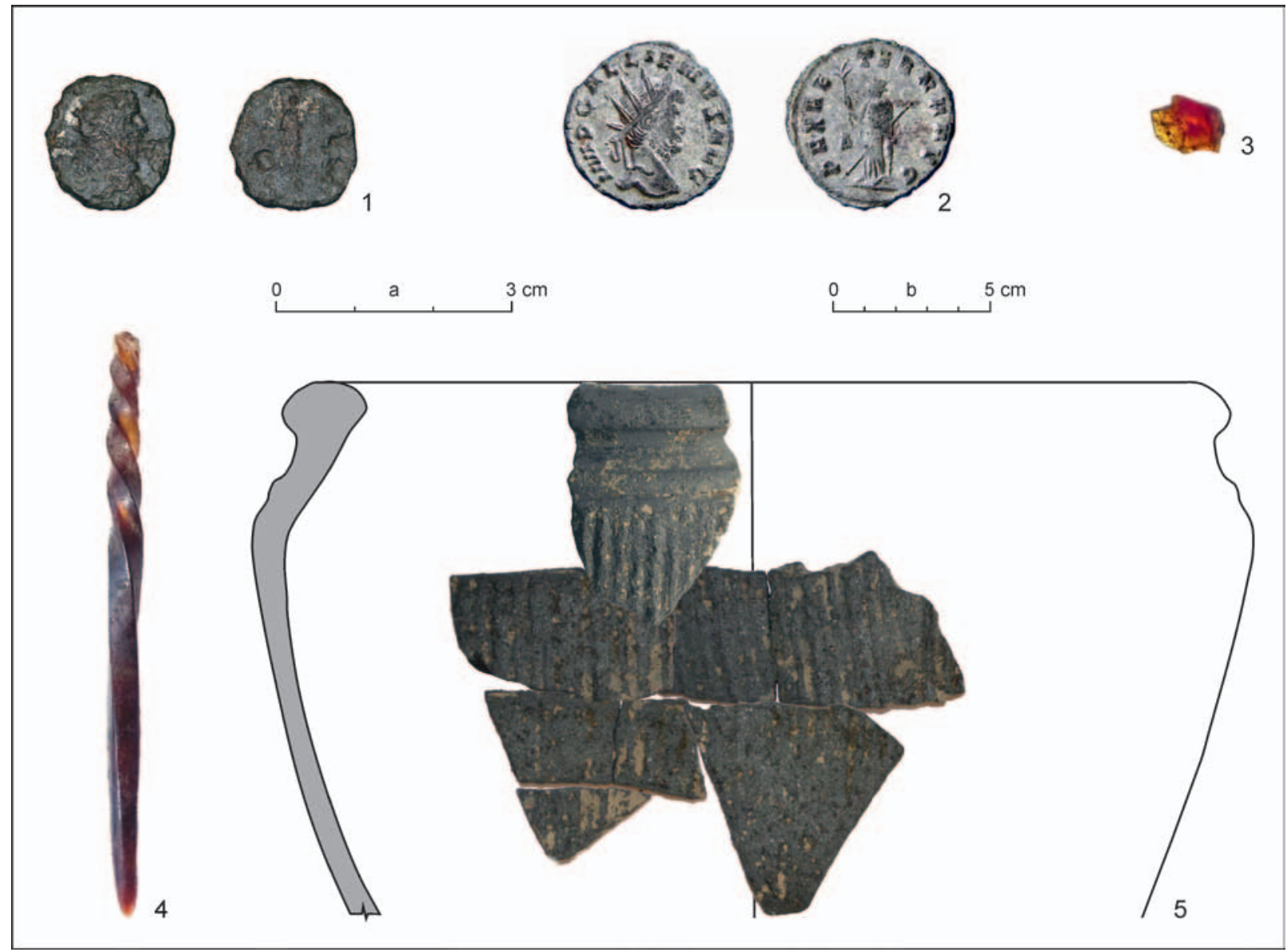

Fig. 1. Pustý hrad Castle in Zvolen, Upper castle. The southern line of the medieval fortification. Trench 1A/2018. Selected protohistoric finds. 1 - subaerat antoninianus of Emperor Gallienus; 2 - an illustrative image of Emperor Gallienus Antoninianus (RIC 252) with a similar image on the averse and reverse as on the coin from the Pustý hrad Castle (https://www.wildwinds.com/coins/ric/gallienus/RIC_0252.jpg); 3 - fragment of a raw piece of amber; 4 - amber needle; 5 Middle La Téne vessel (photo M. Čierny, J. Beljak, drawing N. Beljak Pažinová). Scale: a - 1, 3, 4; b - 5; without scale - 2.

\section{THE SETTLEMENT AT THE SITE OF PUSTÝ HRAD CASTLE IN ZVOLEN}

The monument spreads over two tops of the hill with the same name, which is located at the southwestern edge of the town of Zvolen, in the Javorie hills, above the confluence of the Hron river and the Slatina stream. The site is known mainly thanks to medieval builders, as Hungarian kings from the Árpád family had a massive stone castle built there in the Middle Ages; its catchment area used the natural properties of the site (Fig. 3). On the hilltop plateau (571 $\mathrm{m}$ a.s.l.), the Upper castle with an area of 3.5 ha was built by the end of the $12^{\text {th }} \mathrm{c}$. and lower (476 $\mathrm{m}$ a.s.l.), the Lower castle of 0.7 ha was built in the first half of the $13^{\text {th }} \mathrm{c}$. The massive seat lost its fortifying function gradually, in the $14^{\text {th }} \mathrm{c}$. At the beginning of the $15^{\text {th }} \mathrm{c}$., it was not renewed (Beljak/Beljak Pažinová/Šimkovic 2018, $19-28,50-52)$.
The Pustý hrad Castle hill still has an excellent strategical location with a good view of the Zvolenská kotlina basin and its wider surroundings. Therefore, it is no surprise that this area was popular with settlers since prehistory. The oldest recorded settlement comes from the Late Stone Age, when - mainly at the site of the Lower castle - an upland settlement from the end of the Baden culture was located (Beljak et al. 2014; Beljak Pažinová/Niklovál Beljak 2015). The settlement from the Late Bronze Age, when a hillfort of the Lusatian, later Kyjatice, cultures was built, is dominant in the framework of prehistoric periods. Its collapse is dated to the turn of stages $\mathrm{HB}$ and $\mathrm{HC}$, when a crisis (depopulation) affected also other territories settled by the Kyjatice culture in the Carpathian territory (Beljak/Putško/ Beljak Pažinová, in press).

The Pustý hrad Castle hill was not ignored in Protohistory either. On the hilltop plateau, La Tène sherds of the Púchov culture are sporadically discov- 


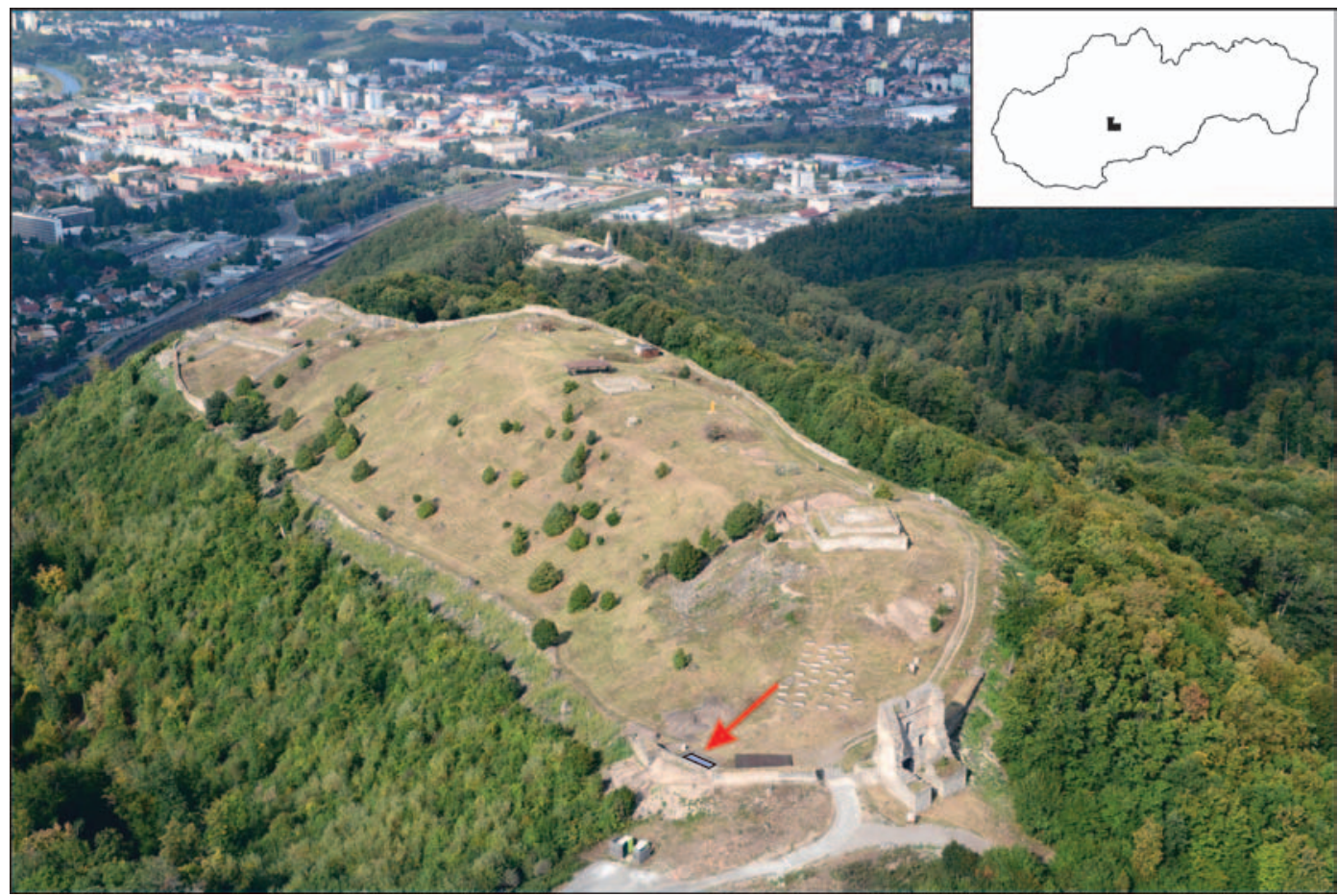

Fig. 2. Pustý hrad Castle in Zvolen. Aerial image of the medieval castle. In the foreground the Upper castle, in the background the Lower castle and the town of Zvolen. Purple colour and red arrow mark the trench 1A/2018 (photo J. Beljak).

ered and two iron brooches from the end of the Late La Tène (LTC2 and LTD1) period were also found (Beljak et al. 2014, 125) as well as fragments of glass bracelets. Torsos of graphited vessels, including fragments of a pot with reinforced rim, short neck with a plastic ring and the body roughened by vertical grooves (Fig. 1:5) from the $2^{\text {nd }} c$. BC (LTC2) were identified also in trench 1A/2018, from which the find of the presented Roman coin comes as well. The nearest settlement of the Púchov culture was located at the site of Haputka, just below the Pustý hrad Castle (the castle's entrance area), another settlement is known from the site of Zvolen-Balkán on the opposite side of the Slatina river running below the Pustý hrad Castle hill (more details in Beljak 2018, 35, 36). The Púchov culture's population was the last for long centuries to have permanently occupied the hilltop plateau of the Pustý hrad Castle. Finds of decorated sherds dated to the $10^{\text {th }}-11^{\text {th }} \mathrm{c}$. discovered near the eastern line of fortification on the hilltop plateau of the Upper castle were considered to be the last traces of settlement before the construction of the royal castle (Beljak/Beljak Pažinová 2018, fig. 21; Beljak/Beljak Pažinová/Šimkovic 2018, fig. 24; Šimkovic/Beljak/Maliniak 2011, 6, 27, 29). A new chapter of the previously unknown history of the site has been opened by the find of the subaerat, which suggests certain movement at the site in the Late or Final Roman Period.

\section{Description of the coin}

The Roman Empire, Gallienus (253-268 AD), subaerat antoninianus, 'from years 260-268 AD' (Fig. 1: 1).

Obverse: Emperor's head on the right with a radial crown, legend: GALLI...

Reverse: A figure standing on the left, illegible legend.

Note: The coin has a bronze core plated with silver.

Weight: $2.28 \mathrm{~g}$

Diam.: $16.76 \times 18.05 \mathrm{~mm}$

Location Ob./Rv.: $6 \mathrm{~h}$

Identification: RIC V 2001, 129-190.

Year of discovery: 2018

Location of find: Pustý hrad Castle in Zvolen, the site of Upper castle, trench 1A/2018 (approx. $560 \mathrm{~m}$ a.s.1.)

The coin discovered at the Pustý hrad Castle in Zvolen is a historical counterfeit, a so-called subaerat, which was very carefully produced. Their cores were made of non-ferrous metals or alloys. The coin from the Pustý hrad Castle had a copper core which was either plated with silver foil attached to the copper core by heating or a piece of alloy of silver and copper and a melting additive was placed on a disc. Surface tension made the alloy flow evenly and cover the whole disc (Stoklas 2017, 23). After being slightly heated, the disc was joined to the foil by a strike of a hammer, i.e. impact of a die. Although the silver foil has fallen off most of the surface and the legends on the obverse and reverse are almost impossible to 


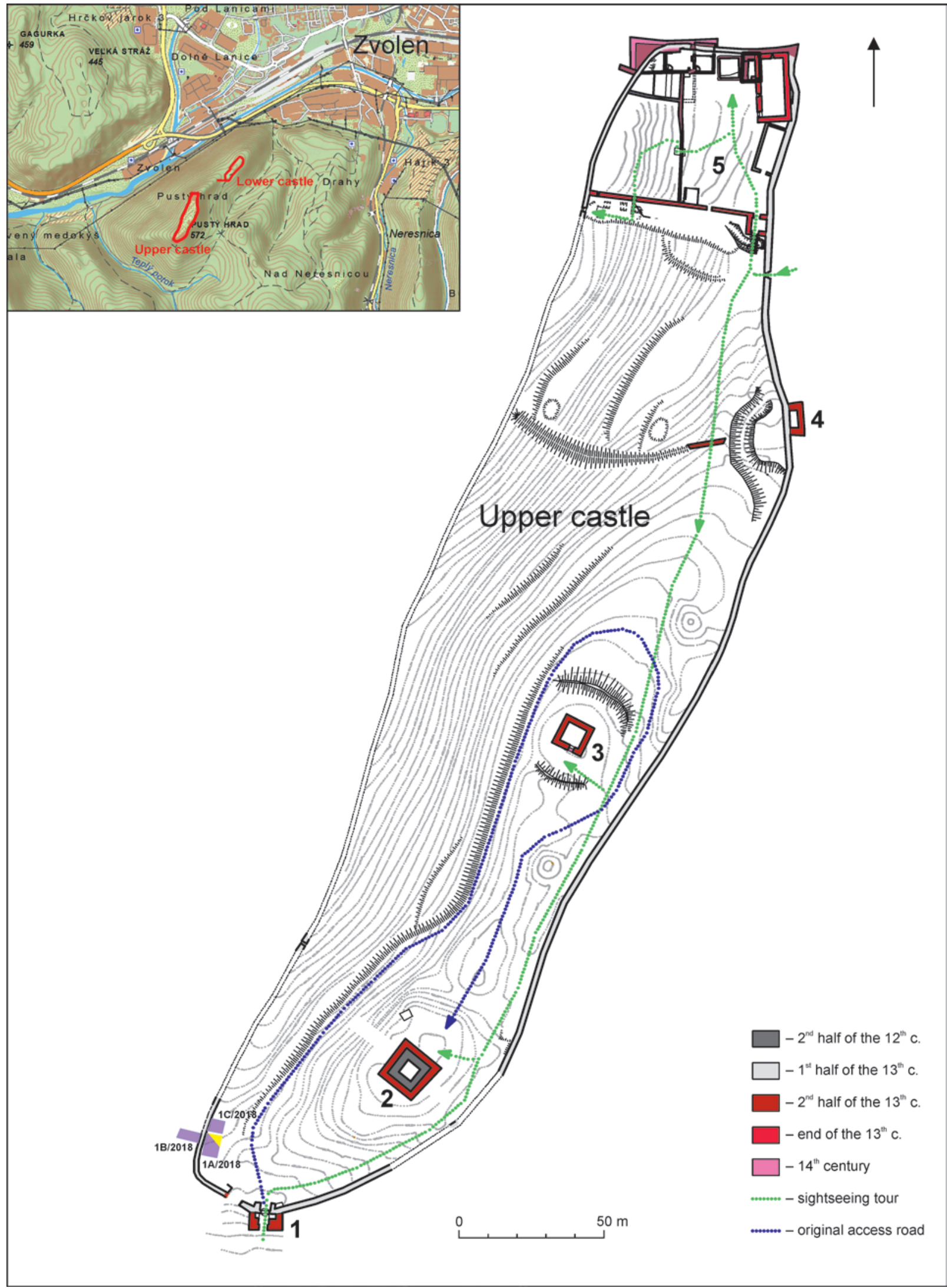

Fig. 3. Pustý hrad Castle in Zvolen. Ground plan of the Upper castle with construction phases. 1 - entrance gate; 2 - tower I. (oldest castle); 3 - tower II.; 4 - flanking tower in the eastern line of fortification; 5 - the area of the so-called Donč Castle. Purple painted trench 1/2018 and with yellow marked the layer with the subaerat antoninianus (author N. Beljak Pažinová). 


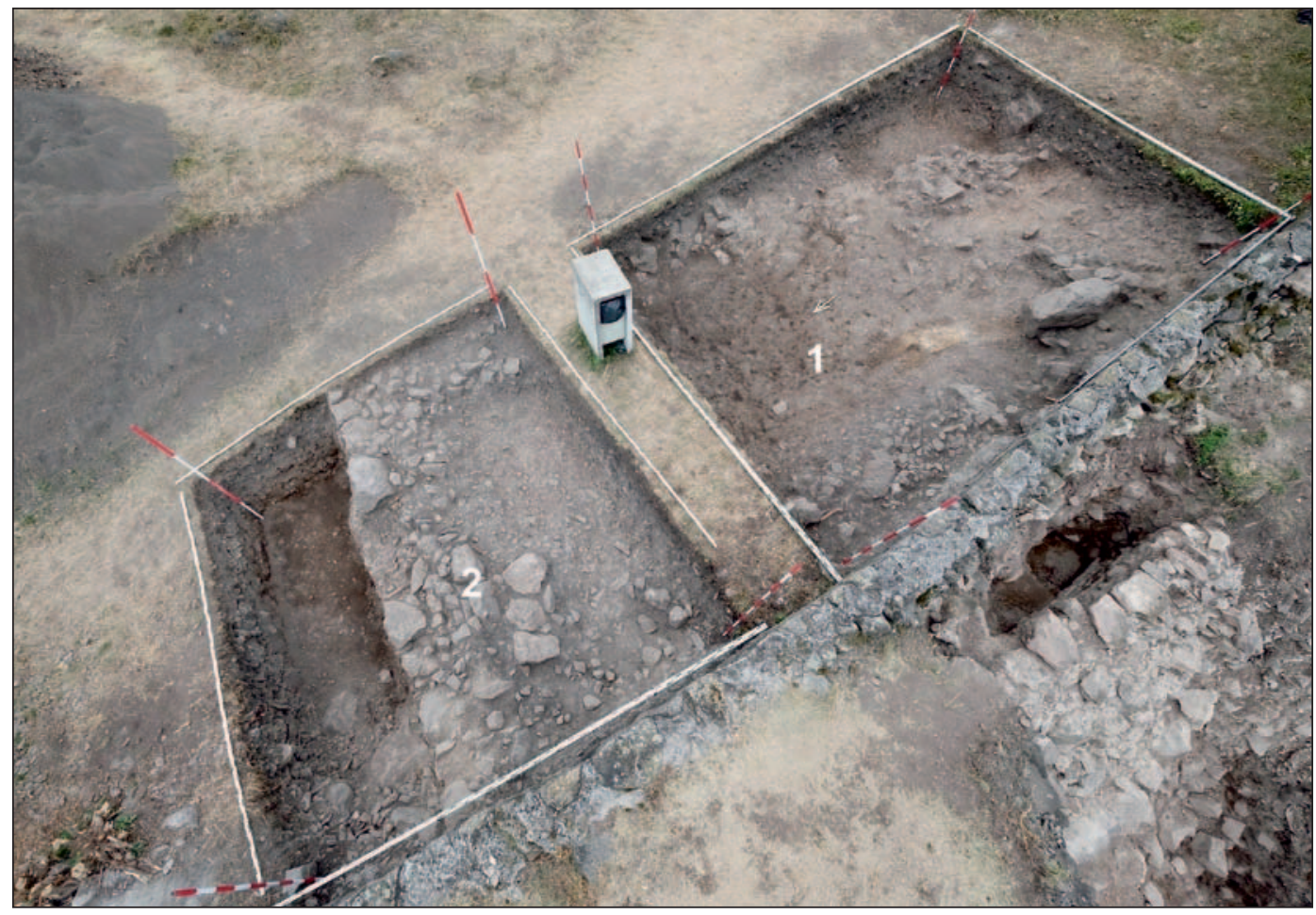

Fig. 4. Pustý hrad Castle in Zvolen, Upper castle. The southern line of the medieval fortification. Trench 1A/2018 (right) and 1C/2018 (left). 1 - a remnant of a medieval log cabin with a mortar floor; $b$ - a younger medieval log building with sustaining wall (photo J. Beljak).

read, a well visible part of the legend on the obverse has been preserved. By this, we can identify the emperor depicted on the coin. The inscription GALLI... can be associated with legends saying GALLIENVS AVG or GALLIENUS P AVG. These legends together with the portrait design are typical of coins from Gallienus's absolutism in 260-268 AD.

\section{IMPORTANT FACTS ASSOCIATED WITH THE DISCOVERY OF THE HISTORICAL} COUNTERFEIT OF AN ANTONINIANUS AT THE PUSTÝ HRAD CASTLE IN ZVOLEN

The coin discovered at the Pustý hrad Castle in Zvolen is an interesting and from the aspect of numismatics, also important find. To prove its uniqueness and exceptionality, we will focus on four crucial facts.

\section{Find context and location}

The artefact was discovered when the course of the southern line of the medieval fortification of the Upper Pustý hrad Castle west of the main entrance gate was being uncovered. Trench 1/2018 situated there was divided into three sectors. Sector $1 \mathrm{~B}(7 \times 3 \mathrm{~m})$ was located in the exterior part of the castle, near the external face of the southern line of the medieval fortification. In this part, presence of a prehistoric stone-earthen rampart under the medieval curtain wall was verified and the trench confirmed that the fortification of the medieval Upper castle covering an area of 3.5 ha was built as early as the end of the $12^{\text {th }}$ or the beginning of the $13^{\text {th }} \mathrm{c}$. at the latest.

Near the interior face of the fortification (Fig. 4), sectors $1 \mathrm{~A}(5 \times 7 \mathrm{~m})$ and $1 \mathrm{C}(4 \times 4.5 \mathrm{~m})$ were located. Stone foundation wall was confirmed there, documenting a medieval log building added to the interior face of the fortification in the $13^{\text {th }} \mathrm{c}$. An older $\log$ cabin with a mortar floor from the $13^{\text {th }} \mathrm{c}$. was also added to the southern curtain wall.

As many as 13 stratigraphic units altogether were detected in the area of trench 1A/2018 (Fig. 5). When the first top layer of forest hummus was removed, a stone-loam layer was recognizable in the southeastern part of the trench. It was composed mostly of smaller stones with the occurrence of finds from the High Middle Ages. A compact stone-earthen structure (construction?) was running in the middle of the trench. In this layer, the Roman coin of emperor Gallienus was found. It was not discovered in the 


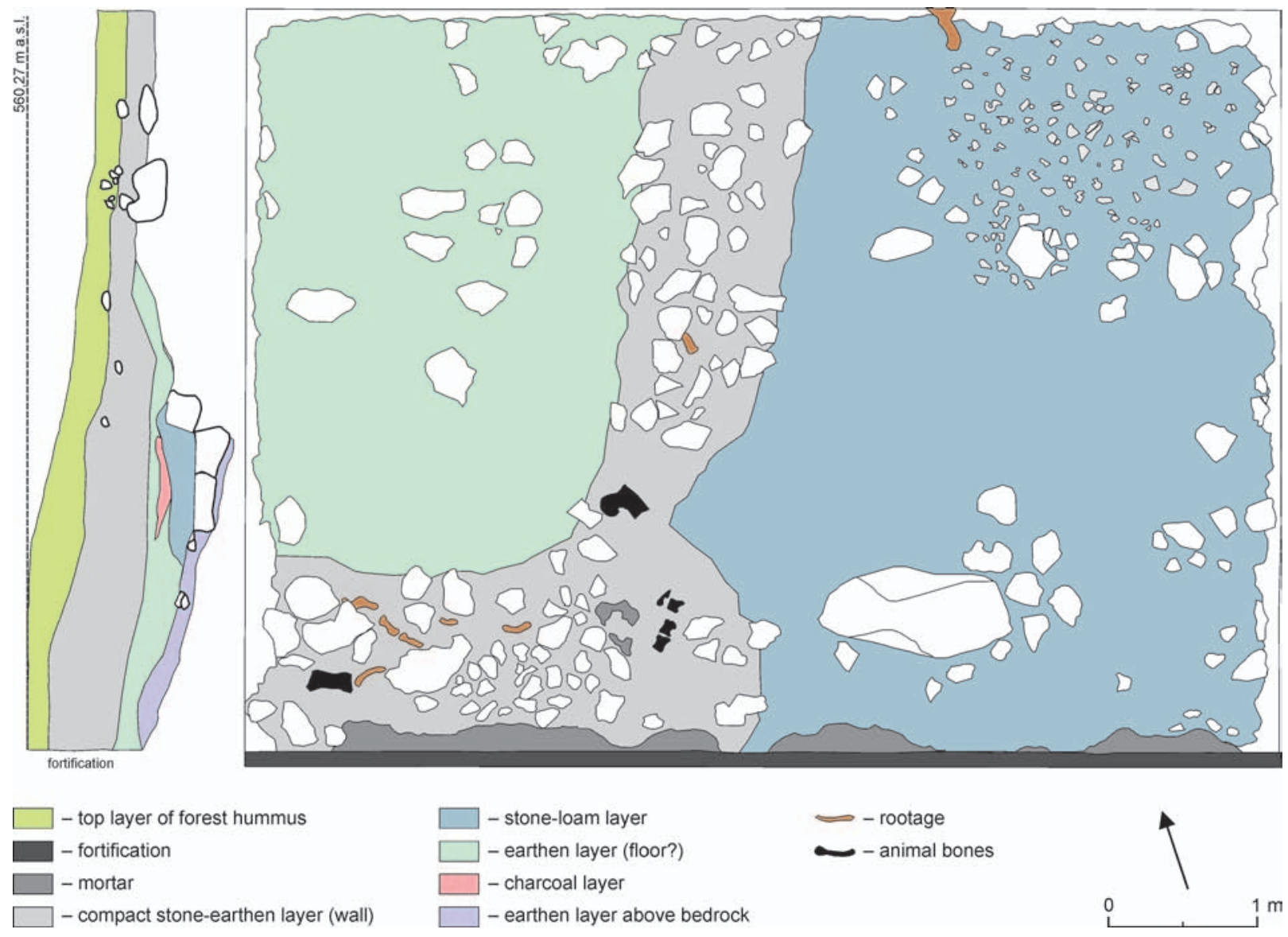

Fig. 5. Pustý hrad Castle in Zvolen, Upper castle. The southern line of the medieval fortification. Trench 1A/2018. Drawing of the floor plan and profile of the trench with cultural layers and finding situations (drawing A. Loydl).

trench itself; it was withdrawn from the layer during sifting and use of metal detector. ${ }^{2}$ Identification of the artefact as a coin was possible after it had been cleaned and conserved. Other unique finds from protohistory also come from the same layer. They are a torso of a modified pin(?) made of amber (Fig. 1:4) and another small unprocessed piece of amber (Fig. 1: 3). Such finds made of organic material are not unknown in the Roman environment thanks to the flourishing trade relations along the Amber Route (Pliny the Elder, XXXVII: 35, 36; Tacitus, 45). In the north-western corner of trench $1 \mathrm{~A} / 2018$, several sherds of graphited vessels from the end of the Middle La Tène Period (Fig. 1: 5) and fragments of glass bracelets were also discovered. Finds from the La Tène Period were previously detected only in the northern part of the castle area and are thus a very important clue for possible detection of La Tène settlement in other parts of the large bailey of the medieval castle. An important fact following from the stratigraphic situation in trench $1 \mathrm{~A}$ is that the protohistoric finds were found in secondary locations in the mixed layer from the High Middle Ages in max. depth of $0.3-0.4 \mathrm{~m}$ below the current terrain surface.

\section{Age of the coin, its identification and dating}

Although the coin is badly preserved, some features can be recognized and thus, the coin can be identified and roughly dated. Some features of the preserved part of the portrait, such as its longer neck and end of the portrait in the lower part, are not common on antoninianus from the $3^{\text {rd }} c$. They are rare only on coins of Antoninus IV Elagabalus and Gallienus. Such portrait edge is more typical of older coins from the $1^{\text {st }}$ and $2^{\text {nd }} \mathrm{c}$. AD, on denarii.

Models for historical fake coins were usually older coins minted with often longer time-lapse, since the time of subaerat coins production. The discovered coin is a model of an antoninianus, which was the leading face value of the Roman monetary system of the $3^{\text {rd }} \mathrm{c}$. AD. Its name is derived from

\footnotetext{
2 For the discovery, we wish to thank our colleague Ivan Trnka for his precise work at searching for finds.
} 
the name of an emperor from the Severan dynasty, Antoninus III, so-called Caracalla (211-217 AD), who ordered its minting in 214 AD.

Antoninianus is characterized mainly by the portrait of the emperor with a radial crown or by the location of an emperor's or empress's bust on a crescent. The radial crown on the emperor's head is a symbol of the double face value as well as two other lower or higher face values of the monetary system, such as dupondius or double aureus (binio; Vondrovec 2007, 310) from the reign of emperor Gordianus III (238-244 AD) to the monetary reform of emperor Diocletianus (284-305 AD) in 294 AD, which cancelled their production. The model was, thus, the coin of emperor Gallienus minted between 260 and 294 AD. However, the fake coin cannot be dated. We can only estimate its occurrence sometime between 260 and $276 \mathrm{AD}$, since the last silver, or billon, coins in the central European Barbaricum come from the beginning of the emperor Probus's reign (276-282 AD), although a little later occurrence before the year of Diocletianus' reform cannot be excluded either.

\section{Technology of production of the coin and its possible use}

The find of the subaerat deserves our attention from the technological as well as a material point of view. Around the middle $3^{\text {rd }} \mathrm{c}$. $\mathrm{AD}$, antoninians become more frequent. They came from official mints, however, the silver they contained was only found on their surface. They were produced by a different technology than subaerat coins. Mercury was used for silvering and when it evaporated, silver precipitated on the surface of the coin (Stoklas 2017, 23). Coins silvered using this technology have been known from older periods, too. Such antoninians are accompanied - for some time - with silver or billon mints and, thus, we cannot be certain if these are official coins or counterfeits or if such coins with the silvered surface are contemporary with their silver counterparts. After $260 \mathrm{AD}$, there are fewer coins with silvered surface and in the final third of the $3^{\text {rd }} \mathrm{c}$. $A D$, they are considered official mints. The coin from the Pustý hrad Castle in Zvolen was subject to a metallographic analysis, ${ }^{3}$ which showed the following proportions of metals: $\mathrm{Cu} 74,9 \% ; \mathrm{Ag}$ 10,88\%; Pb 6,53\%; Fe 5,29\%; Sn 2,03\%; Zn, 0,25\%; Ti $0,23 \%$; Au $0,20 \%$. The higher proportions of lead, iron and tin are not surprising, since their presence in such amounts is typical for subaerat coins. Except for tin, these elements with low proportions are traces of a coin disc's modification (Peter 1990, 85, 87). From the aspect of material as well as technology, we can state that the find represents a silver-plated subaerat coin.

The historical counterfeit coin is probably associated with the settlement of the region in the Late Roman Period. The latest numismatic research has shown that antoninians as well as some of their contemporary counterfeits were used in the territory settled by the Suebi as late as the Late Roman Period. They are present in considerable numbers in currently known hoards of coins from late antiquity (Stoklas/Hrabkovský 2019). Finds of other, denarius subaerat, coins sometimes even occur at Suebi settlements from the Late Roman Period and the beginning of the Great Migration Period. The best example is the find of a subaerat denarius of emperor Hadrianus in the fill of feature 107/65 from the late Suebi settlement in Zlechov (Uherské Hradiště distr.), which was archaeologically dated through other finds from the fill to the course of the $4^{\text {th }}$ c. AD (Militký/Zeman 2007, 184, 185). Historical counterfeits of this kind had the same function in the Germanic environment as in the territories of provinces. For certain, the goal was to deceive and cause financial harm to the coin's receiver. The function of such coins in the territory of Barbaricum, however, remains a question. We suppose that due to frequent damages to such coins revealing their core and leaving very little silver material on the surface, they could still have been used as money, however, having a value of some of the late antique bronze coins. Nevertheless, this is just a hypothesis, since the archaeological situations from the Late Roman barbarian settlements do not allow confirmation of such statements.

\section{Historical context, or where other subaerat antoninians were discovered}

The much more frequent occurrence of subaerat antoninians in the territory of the Roman provinces at the Middle Danube than in the territory of the central European Barbaricum leads us to the statement that these historical counterfeits originated in coiners' workshops in the territory of the Roman Empire. The subaerat antoninians with their models dated after $260 \mathrm{AD}$ are very rare in the provincial environment. In the territory of

\footnotetext{
3 AGLE III $\mu$ Probe - energy-dispersive X-ray fluorescence spectrometer; anode: Rh (Rodium), high voltage: $40 \mathrm{kV}$, Current: $20 \mu \mathrm{A}$. X-ray diam.: $300 \mu \mathrm{m}$ (monocapillary), lenght of measurement: 100s, detector: semiconductive $\mathrm{Si}(\mathrm{Li})$ with active surface

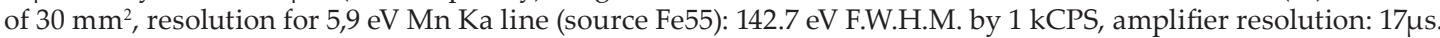


Slovakia, i.e. former barbarian territory, we have not recorded such young subaerats at all. This fact makes the new find from central Slovakia even more interesting.

The nearest analogy can be found in the find of Roman coins from the area of Brigetium (Komárom-Szőny), which was an important military point and a distribution centre of the Roman goods heading for the Barbaricum in the Roman Period (Hečková 1982, 26). A subaerat coin with the model of the emperor Gallienus's antoninianus from 266-267 AD with the emperor's head on the obverse bearing a radial crown and turned right was also discovered there. The coin's reverse depicts goddess Pax standing on the left, holding an olive branch and a transversely oriented long sceptre (Fig. 1: 2; after the numismatic catalogue RIC V 2001, 153, no. 253). The reverse of this coin is significantly similar to the find from the Pustý hrad Castle, although the depicted goddess cannot be identified with certainty. One more subaerat antoninianus made after the model from $265 \mathrm{AD}$ was found among the finds from this site (Lányil Redő/Torbágyi 1999, 236). There were also other finds of subaerat antoninians corresponding with the models by emperor Aurelianus (270-275 AD) and emperor Probus (276-282 AD). There were three exemplars of the first and two of the second (Lányi/Redö/Torbágyi 1999, 242, 243). Another such find of a subaerat coin minted after 260 AD comes from Esztergom (Komárom-Esztergom Comitatus), which was also a trade and production centre on the Roman-Quadi border zone called Solva by the Romans. There, a historical counterfeit of the emperor Aurelianus's antoninianus (270-275 AD) was found. It had no find context either and was only accidentally found in the catchment area of the former Roman camp (Lányi/Redö/Torbágyi 1999, $135,242)$. Interestingly, no other analogies of such historical subaerat counterfeits of antoninianus were discovered in the border area of today's Hungary and Austria and all the above-mentioned finds are concentrated in the northern border area of the former province of Pannonia Inferior adjacent to the territory of the Quadi. A trade route started there along which Roman goods travelled northwards, to the barbarian territory (Beljak 2014, 298).

Several finds of subaerat Roman coins and other historical counterfeits come from the territory of western Slovakia. However, they only make up a small fragment of all finds of Roman coins in this territory. A subaerat denarius of Iulia Domna comes from Bohdanovce nad Trnavou, Trnava distr., a subaerat denarius of Septimus Severus was found in Borský Sv. Jur-Húšky, Senica distr., subae- rat denarii of Traianus and Septimus Severus come from the Germanic settlement in Chotín-Horné Konopište, Komárno distr. (Stoklas 2017, 23). The most recent addition to this special collection of coins is a perforated subaerat denarius of emperor Hadrianus from Želiezovce, Levice distr. (Bazovskýl Budaj 2020, 44).

Counterfeit Roman coins also come from the area of the Roman military camp in Iža- Leányvár (Nemeškalová-Jiroudková 1972). They were coins of the crew's soldiers or coins from their pay or the circulation on the opposite side of the Danube. They are represented by a silvered denarius of emperor Hadrianus, an unidentifiable subaerat denarius from the $1^{\text {st }}-2^{\text {nd }} \mathrm{c}$. $A D$ and an unidentifiable subaerat antoninianus from the $3^{\text {rd }} \mathrm{c}$. AD.

As far as the find of the antoninianus with the portrait of probably Philipp I (244-249 AD) from the Germanic settlement in Bohdanovce nad Trnavou, Trnava distr. and the antoninianus of Gordianus III (238-244 AD) from the settlement in HurbanovoHurbanovský potok stream, Komárno distr. (Stoklas 2017, 23) are concerned, we cannot be positively sure if they are counterfeits. This could be suggested by their rare occurrence among the mints dated between 238 and $253 \mathrm{AD}$ as well as much more frequent silver-plated subaerat coins.

\section{DISCUSSION}

Processing of the unique find of the subaerat from the Pustý hrad Castle in Zvolen has brought some new historical evidence. The most essential ones include the fact that it is an artefact that arrived at the site probably in the Late to Final Roman Period and is associated with the movement of the Germanic population in the territory of the Zvolenská kotlina basin in central Slovakia. According to the previously known archaeological sources, the Quadi settled this region more intensely as late as the beginning of the Late Roman Period (last decades of the $2^{\text {nd }}$ c. AD), i.e. shortly after they had arrived at the lower Pohronie region (Beljak 2009, 215). The reasons behind the shift of the Germanic settlement to the mountain basins of central Slovakia could include the increase of population, development of the Germanic society in the favourable Severan period as well as interest in the exploitation of ore sources in this space. The furnace discovered at the site of ZvolenHaputka (Beljak 2009; Hanuliak/Malček/Pieta 2000, $47,48)$ located on the north-eastern foothill of the Pustý hrad Castle hill is evidence of metallurgic activity of the first Quadi generation in the central Pohronie region. 
The presence of the Quadi population in the Late and Final Roman Period $\left(3^{\text {rd }}-4^{\text {th }}\right.$ c. AD) is documented mainly in form of pottery finds from the Zvolenská, Žiarska and Pliešovská basins (more information in Beljak 2006; 2018, 36-40; Beljak/ Kučeráková 2015; Beljak/Malček 2009; Pieta/Mosný 1990). The region of Horehronie located further to the north, which remained unsettled after the extinction of the Púchov culture at the beginning of the $1^{\text {st }}$ c., is occupied by the Germanic people/ Quadi as late as the Final Roman Period. Traces of their material culture are documented mainly in the L’upčianska kotlina basin (Mosný 1998).

As for finds of Roman coins in this region, two bronze coins of Roman emperors Constantius I and Constantius Gallus discovered in the northern part of the Zvolenská kotlina basin, in the allotment's colony under Suchý vrch hill in Banská Bystrica (Mácelová 1992) were detected as stray finds.

The settlement at upland sites in the mountainous areas in the central and upper Pohronie region is a phenomenon of the Late Roman Period and the beginning of the Great Migration Period. It is not a permanent settlement; it is often only sporadic use of elevated protective sites. Finds occur at new upland sites (Nemce-Hrádok, Jastrabá-Jastrabá skala, etc.) as well as former hillforts of the Púchov culture (Detva-Kalamárka, Horné Pršany-Vel'ký hrádok, Hrochot-Chochulka, Hrochot'-Jánošíkova skala, Selce-Hrádok, Šášovské Podhradie-Šášov Castle, etc.), which might be the case of the Pustý hrad Castle hill. It is an expression of the unsteady situation at the turn of the $4^{\text {th }}$ and $5^{\text {th }}$ c. AD (Fusek/ Zábojník 2003, 324). It is also important, that trade contacts with Pannonia were not interrupted in that period. The pottery production of Roman provinces is represented at the sites by the Pannonian coarse grey pottery in form of storage vessels and bowls (Beljak 2014). The fragment of a glass cup with a fused fibre from Detva-Kalamárka (Šalkovský 2002, fig. 61: 5) which can be dated from the last third of the $4^{\text {th }} \mathrm{c}$. to the first decades of the $5^{\text {th }} \mathrm{c}$. AD is also considered an import. The coin found at the Pustý hrad Castle was a Roman coin commonly used in the payment system in the barbarian environment.

Finally, one more interesting fact should be mentioned in the end of the discussion. The find of a historical counterfeit of a Roman coin discovered at the Pustý hrad Castle in Zvolen is not the only find of Roman money in the territory of a medieval castle in Slovakia. A historical counterfeit denarius of Septimus Severus with tinned surface was discovered during the archaeological excavation at the Devín Castle in 1973, in one of the medieval economic buildings located in the central part of the castle (Stoklas 2017, 23, 24; 2018, 47).

\section{CONCLUSION}

This article aimed to draw attention to and analyse a unique find of a Roman coin - a historical counterfeit of an antoninianus of emperor Gallienus, which was most probably minted in the last decades of the $3^{\text {rd }} \mathrm{c}$. AD. It was a rather unexpected find discovered with a metal detector in the mixed cultural layer of the bailey near the main entrance gate to the Pustý hrad Castle in Zvolen. When trench 1A/2018 located near the interior face of the southern line of the medieval curtain wall at the Upper castle was being excavated, a badly preserved corroded round plate was found. After it had been cleaned and conserved, it was identified as a Roman coin.

The thorough analysis of the artefact points to the fact that it is a historical counterfeit that arrived at the site in the Late or Final Roman Period. Although historical counterfeits are rather frequent in the territories of former Roman provinces, their numbers among finds from the Middle Danube Barbaricum are significantly lower. The artefact was probably associated with the settlement of the Germanic tribe of Quadi in the territory of the Zvolenská kotlina basin. We consider it a Roman coin and also evidence of the activity of contemporary counterfeiters who joined the copper core with silver foil by striking a hammer against a punch after putting the foil on the disc. The find which could have been used in common trade cannot be associated with any specific activity at the site so far, as the protohistoric settlement is very scarce there. On the other hand, we have pointed to the intense settlement activity of the Quadi/Suebi in the Zvolenská kotlina basin and the surrounding areas of central Slovakia. Therefore, it was just a question of time when traces of this historical period would be identified at the upland site of the Pustý hrad Castle in Zvolen. The find of the historical counterfeit of an antoninianus helped us fill this period.

The fact that counterfeit coins are not unknown at the Pustý hrad Castle in Zvolen is also interesting. The seat has a long counterfeiting tradition since fake coins were minted right at the royal castle at the turn of the $13^{\text {th }}$ and $14^{\text {th }}$ c. (Hanuliak/Hunka 2000). A postmedieval clay mould for counterfeit coins - 15 Kreutzer of emperor Leopold I from the second half of the $17^{\text {th }} \mathrm{c}$. - comes from the castle as well (Hunka/Beljak Pažinová/Beljak 2021).

The find of the historical counterfeit of an antoninianus of emperor Gallienus from the Pustý hrad Castle in Zvolen is a unique numismatic find not only from a medieval castle in central Slovakia but also from the whole territory of Slovakia since we do not know any similar artefact of a young subaerat antoninianus from the environment of the Transdanubian Barbaricum. 


\section{BIBLIOGRAPHY}

Bazovský/Budaj 2020 - I. Bazovský/M. Budaj: Rímske mince z germánskeho sídliska v Želiezovciach (okr. Levice). Denarius. Numizmatický časopis 8, 2020, 36-55.

Beljak 2006 - J. Beljak: Púchovská kultúra a Germáni na Pohroní v staršej dobe rímskej. In: E. Droberjar/ M. Lutovský (eds.): Archeologie barbaru 2005. Sborník př́spěvkü z I. protohistorické konference "Pozdně keltské, germánské a časně slovanské osídlení." Kounice, 20.-22. zárí 2005. Praha 2006, 257-272.

Beljak 2009 - J. Beljak: Osídlenie vo Zvolene v dobe rímskej na príklade osád Haputka a Balkán. In: M. Karwowski/E. Droberjar (eds.): Archeologia Barbarzyńców 2008: powiazania i kontakty w świecie barbarzyńskim. Materiały z IV Protohistorycznej Konferencji Sanok, 13-17 października 2008. Collectio archaeologica Ressoviensis 13. Rzeszów 2009, 211-228.

Beljak 2014 - J. Beljak: Die quadische Enklave im Granund Eipeltal - Eine Grundcharakteristik der Ansiedlung. In: B. Komoróczy (ed.): Archeologie barbarů 2011. Sociální diferenciace barbarských komunit ve světle nových hrobových, sídlištních a sběrových nálezů. Spisy Archeologického ústavu AV ČR Brno 44. Brno 2014, 295-316.

Beljak 2018 - J. Beljak: Osídlenie Zvolenskej kotliny vo včasnej dobe dejinnej. In: N. Beljak Pažinová/Z. Borzová (eds.): Stredné Slovensko v stredoveku. Vývoj osídlenia regiónu pred udelením mestských privilégii mestu Zvolen. Zvolen 2018, 34-47.

Beljak/Beljak Pažinová 2018 - J. Beljak/N. Beljak Pažinová: Výskum a obnova Pustého hradu vo Zvolene. In: N. Beljak Pažinová/Z. Borzová (eds.): Stredné Slovensko v stredoveku. Vývoj osídlenia regiónu pred udelením mestských privilégií mestu Zvolen. Zvolen 2018, 212-235.

Beljak/Beljak Pažinová/Šimkovic 2018 - J. Beljak/N. Beljak Pažinová/M. Šimkovic: Pustý hrad vo Zvolene a hrad Pet'uša vo svetle aktuálnych výskumov. Zvolen 2018.

Beljak et al. 2014 - J. Beljak/N. Beljak Pažinová/B. Beláček/ M. Golis/J. Hunka/A. Krištín/V. Kohút/P. Maliniak/ M. Mordovin/M. S. Przybyła/D. Repka/M. Slámová/ M. Šimkovic/B. Tóth/O. Žaár: Pustý hrad vo Zvolene, Dolný hrad 2009-2014. Nitra 2014.

Beljak/Kučeráková 2015 - J. Beljak/K. Kučeráková: Vývoj osídlenia na strednom Pohroní od doby laténskej do včasného stredoveku. Študijné zvesti AÚ SAV 57, 2015, 7-56.

Beljak/Malček 2009 - J. Beljak/R. Malček: Nálezy z Vígl’aša-Pstruše. AVANS 2007, 2009, 31, 32.

Beljak/Putško/Beljak Pažinová, in press - J. Beljak/M. Putško/ N. Beljak Pažinová: Unusual find of newborn skeletal remains from the Late Bronze Age settlement at Pustý hrad (Deserted castle) in Zvolen (Central Slovakia). In: J. Gancarski (red.): Epoka brazu i wczesna epoka żelaza $w$ Karpatach, in press.

Beljak Pažinová/Beljak 2020 - N. Beljak Pažinová/J. Beljak: Benefits of the long-term research of the Pustý hrad castle (Deserted castle) in Zvolen and its prospects for the future. Archaeologia historica 45, 2020, 941-956. DOI: https://doi.org/10.5817/AH2020-2-20

Beljak Pažinová/Niklová/Beljak 2015 - N. Beljak Pažinová/ M. Niklová/J. Beljak: Deserted castle - Lower castle in
Zvolen in the context of the Baden Culture settlement in Middle Gran region. In: M. Nowak/A. Zastawny (eds.): Via Archaeologica. Źródła z badań wykopaliskowych na trasie autostrady A4 w Małopolsce. The Baden culture around the Western Carpathians. Kraków 2015, 395-411.

Fusek/Zábojník 2003 - G. Fusek/J. Zábojník: Príspevok do diskusie o počiatkoch slovanského osídlenia Slovenska. Slovenská archeológia 51, 2003, 319-337.

Hanuliak/Hunka 2000 - V. Hanuliak/J. Hunka: Poklad mincí z Pustého hradu pri Zvolene. Archaeologia historica 25, 2000, 359-367.

Hanuliak/Malček/Pieta 2000 - V. Hanuliak/R. Malček/ K. Pieta: Záchranný výskum vo Zvolene. AVANS 1999, 2000, 47-49.

Hečková 1982 - J. Hečková: Podiel výrobných centier rímskych provincií na spoločensko-ekonomickom vývoji naddunajského barbarika vo svetle rímskych importov. Slovenská archeológia 30, 1982, 5-77.

Hunka 2013 - J. Hunka: Mince Arpádovcov z rokov 1000-1301. Ich podiel na vývoji hospodárstva stredovekého Slovenska. Archaeologica Slovaca Monographiae. Studia 15. Nitra 2013.

Hunka/Beljak Pažinová/Beljak 2021 - †J. Hunka/N. Beljak Pažinová/J. Beljak: Hlinená forma na odlievanie falošných mincí z Pustého hradu vo Zvolene. Studia Historica Nitriensia 25, 2021, 85-97.

DOI: https://doi.org/10.17846/SHN.2021.25.1.153-165

Kolníková 1978 - E. Kolníková: Keltské mince na Slovensku. Dávnoveké umenie Slovenska 2. Bratislava 1978.

Lányi/Redő/Torbágyi 1999 - V. Lányi/R. Redő/M. Torbágyi: Die Fundmünzen der römischen Zeit in Ungarn. Band III. Komitat Komárom-Esztergom. Berlin - Budapest 1999.

Mácelová 1992 - M. Mácelová: Nález rímskych mincí v Banskej Bystrici. AVANS 1990, 1992, 72.

Militký/Zeman 2007 - J. Militký/T. Zeman: Nálezy ř́mskych mincí na sídlišti ze sklonku doby římské a počátku doby stěhování národů ve Zlechově (okr. Uherské Hradiště). Numismatický sborník 22, 2007, 183-187.

Mosný 1998 -P. Mosný: Výsledky prieskumu v L’upčianskej doline. AVANS 1996, 1998, 120.

Nemeškalová-Jiroudková 1972 - Z. NemeškalováJiroudková: Oběh mincí v oblasti římskeho kastelu v Iži na Leányváru. Slovenská numizmatika 2, 1972, 115-131.

Pažinová et al. 2013 - N. Pažinová/J. Beljak/M. Slámová/ B. Beláček: Stredoveká cestná siet v okolí zvolenského Pustého hradu. Analýza na základe antropogénnych reliéfnych foriem. Študijné zvesti AÚ SAV 54, 2013, 153-170.

Peter 1990 - M. Peter: Eine Werkstätte zur Herstellung von subaeraten Denaren in Augusta Raurica. Studien zu Fundmünzen der Antike. Band 7. Berlin - Mann 1990.

Pieta/Mosný 1990 - K. Pieta/P. Mosný: Prieskum sídlisk z doby rímskej na strednom Pohroní. AVANS 1988, 1990, 139, 140.

Pliny the Elder - G. Plinius Starší: Kapitoly o přírodě. Praha 1974. 
RIC V 2001 - H. P. Mattingly/A. E. Sydenham/H. P. Webb: The Roman Imperial Coinage. Volume 5, Part 1. Valerian I to Florian. Reprinted. Stroud 2001.

Šalkovský 2002 - P. Šalkovský: Výšinné hradisko v Detve-protohistorické osídlenie. Slovenská archeológia 50, 2002, 100-124.

Šimkovic/Beljak/Maliniak 2011 - M. Šimkovic/J. Beljak/P. Maliniak: Zvolenský Pustý hrad. Sprievodca po hrade. Zvolen 2011.

Stoklas 2017 - B. Stoklas: Napodobneniny a falzá rímskych mincí v oblasti stredodunajského barbarika z 1.-3. storočia po Kr. Numizmatika 27, 2017, 19-26.

Stoklas 2018 - B. Stoklas: Nálezy mincí z doby rímskej v katastrálnom území Bratislava-Devín od počiatkov archeologických výskumov po súčasnost'. Denarius. Numizmatický časopis 7, 2018, 35-51.

Manuscript accepted 5. 10. 2021

Translated by Viera Tejbusová

PhDr. Ján Beljak, PhD.

Archeologický ústav SAV

Akademická 2

SK - 94921 Nitra

jan.beljak@savba.sk

Mgr. Boris Stoklas, PhD.

SNM - Historické múzeum

Oddelenie numizmatiky

Bratislavský hrad

P. O. BOX 13

SK - 81006 Bratislava

boris.stoklas@snm.sk
Stoklas/Hrabovský 2019 - B. Stoklas/M. Hrabovský: Staré rímske razby mincí $\mathrm{z}$ oblasti stredodunajského barbarika v neskoroantickom období. Numismatický sborník 33, 2019, 123-138.

Tacitus - P. C. Tacitus: Tacitova Germania, čili, Kniha o poloze, mravech a národech Germanie. Praha 1886.

Vondrovec 2007 - K. Vondrovec: Gesamtdarstellung und Auswertung des antiken Fundmünzmaterials im Museum Carnuntinum. In: M. Alram/F. Schmidt-Dick (Hrsg.): Numismata Carnuntina. Forschungen und Material. Österreichische Akademie der Wissenschaften. Philosophisch-historische Klasse. Denkschriften, 353. Band. Die Fundmünzen der römischen Zeit in Österreich. Abteilung III. Niederösterreich. Band 2. Die antiken Fundmünzen im Museum Carnuntinum. Wien 2007, 55-340.

prof. PhDr. Noémi Beljak Pažinová, PhD. Univerzita Konštantína Filozofa v Nitre Tr. A. Hlinku 1

SK - 94974 Nitra

nbpazinova@ukf.sk 
